\title{
The road to happiness is the way to suffering
}

\author{
Marina Alexandrovna Kindzerskaya ${ }^{1 *}$, Tatyana Ivanovna Marmazova ${ }^{1}$, Stanislav \\ Alexandrovich Ruzanov ${ }^{1}$, Pyotr Alekseevich Kostin ${ }^{1}$, and Ilona Vladislavovna Tarasova ${ }^{1}$ \\ ${ }^{1}$ Plekhanov Russian University of Economics, Department of History and Philosophy, Center for \\ Humanitarian Training, Moscow, Russia
}

\begin{abstract}
The article deals with the problem of a person's conscious choice between happiness and suffering. At first glance, happiness and suffering are two different paths, and one should choose which road to take. On the one hand, suffering is an obstacle on the way to oneself, to a happy existence. On the other hand, one chooses suffering and happiness willingly, happiness is proportionate to suffering. One should not forget that existence has no meaning if it brings merely pain and dissatisfaction, so it is very important to strive to be happy. Throughout the entire history of humanity, the problem of happiness and the search for the best way to be released from suffering is a pressing issue. The relevance of the problem is determined by the particular significance of the concepts under study, because every person's natural desire, regardless of the era and area of residence, is to be happy and free. The concepts of "happiness" and "suffering" are not only philosophical but also sociocultural phenomena that expound the axiological and spiritual and moral aspects of human existence. The study features quotes from thinkers of different ages and cultures that to an extent engaged in interpreting the content of the phenomena of happiness and suffering. The purpose of the study is to expound the sociocultural content of the phenomena of "happiness" and "suffering", their causes, and the conditions for coexistence. The main methods of the study are the method of systemic analysis, the comparative method, and the typological method. The novelty of the study consists in the fact that the authors examine the phenomena of "happiness" and "suffering" together for the first time. Although the phenomena are an integral part of human activity.
\end{abstract}

Keywords:sensation, state, happiness, suffering

The subject of happiness is one of the most important for people, this topic permeates all spheres of human life, causes a lot of controversies, gives rise to more and more opinions and beliefs. Indeed, happiness is an ambiguous concept, as each person reads their special, one might say sacred meaning into the concept. Happiness stirs our consciousness and forces us to make certain decisions since this unknown state for many is the meaning of existence. Happiness is measured by one's own inner state which is not always understandable even to the individual, probably, it is cognized only in comparison with suffering.

\footnotetext{
*Corresponding author: kindzerskaya.ma@rea.ru
} 
Everyone puts something of their own in the concept of happiness, which is as immense and boundless as man so it can be contained in every little thing in life, in everything imaginable. The feeling of happiness can be caused by the very fact of life, family, love, nature, friendships, children, pets, or material goods: money, delicious food, new things, and much more. The other side of this phenomenon is the suffering that one feels if one cannot get what one wants.

The object of the study: happiness and suffering as spiritual components of human existence.

The subject of the study: socio-cultural prerequisites for the implementation of the phenomenon of happiness in society and ways of alleviating suffering.

Research objectives:

- Expound the philosophical and sociocultural prerequisites for understanding happiness and suffering.

- Trace the relationship between happiness and suffering, their impact on a person's view of life.

The methodological basis of the study is the philosophical concepts of happiness and suffering as phenomena of human life.

The works by P.S. Gurevich, Yu.M. Lotman, V. Tatarkevich, S.S. Horuzhy significantly impacted the creation of theoretical concepts about the phenomenon of "happiness" presented in the study.

Among modern dissertation research on the topic of happiness in different interpretations, one can highlight the works by the following authors: M.A. Bogdanova, M.N. Koroleva, M.V. Lapukhina, and others. These works investigate the phenomenon of "happiness" from different scientific positions.

The dissertations by M.V. Babalaeva, I.V. Bardykova, Ya. V. Parusimova, and others are devoted to understanding the theme of suffering.

Since ancient times, philosophers have tried to comprehend the essence of suffering, both spiritual and physical, and develop its conceptual and categorical apparatus.

According to the teachings of Buddhism, life is full of suffering, man can stop suffering by abandoning the desire for pleasure. A person can eliminate suffering by attaining nirvana, true "peace of mind" [1].

Since ancient times, the philosophers of Antiquity - Plato, Aristotle, Epicurus, and others tried to comprehend the phenomenon of suffering and understand the reasons for its occurrence, while assuming that suffering is caused by fate.

In the Middle Ages and later, the source framework of research into the concept of "suffering" consisted of works by philosophers Saint Augustine, A. Schopenhauer, F. Nietzsche, N.A. Berdyaev, K. Jaspers and others.

"We have long since recognized this striving, that constitutes the kernel and in-itself of everything, as the same thing that in us, where it manifests itself most distinctly in the light of the fullest consciousness, is called will. We call its hindrance through an obstacle placed between it and its temporary goal, suffering; its attainment of the goal, on the other hand, we call satisfaction, well-being, happiness", wrote A. Schopenhauer. Moreover, the German philosopher concluded that the source of the greatest suffering in the world was the most violent struggle for material wealth [2].

Russian religious philosophy interprets the phenomenon of suffering in its own way. V.S. Solovyov criticizes A. Schopenhauer's point of view while characterizing suffering as "the definition of something through something else, external to it," namely selfishness. Liberation from suffering, according to the philosopher, is achieved through overcoming selfishness [3].

In the philosophy of the Soviet period, the topic of suffering was not considered since it was believed that a Soviet person, a builder of a bright future, should be happy a priori. In 
Western philosophy, on the contrary, the theme of suffering was actively studied from the perspective of existentialism, neo-Freudianism, and other philosophical theories.

"The goal of every person's life is happiness!" asserted the Russian writer M.A. Bulgakov [4].

What is happiness made of? What does a person need to be happy?

In the philosophy of Antiquity, one can find such a "recipe" for happiness: be content with little, do not chase unfulfilled desires. Have as little as possible of what is easy to lose... Thus, to be happy, one should only be content with the essentials in life.

Obtaining excessive material wealth brings a person stress, fatigue, disappointment, which ultimately not only negatively affects the person's health but also significantly shortens their life.

"Not the one who has all the best is happy but the one who makes the best of what one has", taught Confucius [5]. So why is one not content with the minimum but spends one's life on the hustle and the acquisition of excess things, instead of living in harmony with oneself and the whole world? What motivates people who destine themselves to suffer in pursuit of a position in society or for luxury goods, despite their happiness?

The answer to this question may be hidden in the consciousness and sensations of a person. "Only one's thoughts, not external circumstances, make one unhappy or happy. By controlling one's thoughts, one controls one's happiness," wrote the German philosopher F. Nietzsche [6].

One lives life through a set of sensations with which one analyzes and evaluates the existence. Throughout one's life, no matter what one strives for, one strives for happiness, which one hopes to receive through pleasant sensations (for example, the possession of material goods, fame, etc.). However, having achieved prosperity and fame, ony is not always happy, in most cases the opposite.

"Do not pursue happiness: it is always in you", argued Pythagoras [5]. Indeed, what a person has does not matter as much as what sensations a person experiences, whether a person has become happy from the possession of a cherished goal or object, that is, a person experiences happiness through their inner sensations.

"Even in human happiness there is something sad", wrote A.P. Chekhov [7], F.M. Dostoevsky echoes, arguing that "a person, besides happiness, needs just as well and exactly the same amount of misfortune!"[8]. Both happiness and suffering act as incentives for action. One can satisfy one's needs beyond measure, and be unhappy, or one can achieve happiness by reducing one's needs.

"Happiness is a state of mind", wrote André Maurois [9], paraphrasing this statement, we can say that suffering is also a state of a person's mind, prompting a person to act because to alleviate suffering a person is forced to act, look for a way out of this situation.

Thus, along with a conscious striving for happiness, a person on an unconscious level strives for unhappiness which is expressed in suffering. It can be argued that the phenomena of "happiness" and "suffering" are an integral part of human life, stimulating action. A happy person is ambivalent, on the one hand, feeling happy, one is in harmony with oneself, and on the other, one experiences constant dissatisfaction with these states, from which one suffers. If for happiness a person needs little, just to rejoice in what one has, then the pursuit of excesses brings one suffering.

\section{References}

1. D. Chattopadhyaya, What is Living and What is Dead in Indian Philosophy (Progress, Moscow, 1981)

2. A. Schopenhauer, The World as Will and Representation, in Collected works in 4 vol, 1, 410-411 (Nauka, Moscow, 1993) 
3. V.S. Solovyov, Collected works in 2 vol., 1 (Mysl, Moscow, 1990)

4. M.A. Bulgakov, Moler [Molière] (Molodaya gvardiya, Moscow, 1980)

5. D.G. Plisetskii, Mudrye mysli. Izbrannye aforizmy [Wisdom. Selected Aphorisms] (Ripol Klassik, Moscow, 2001). Accessed on: December 5, 2020. [Online]. Available: http://www.livelib.ru/work/1002375072-mudrye-mysli-izbrannye-aforizmy-dmitrijplisetskij

6. F.W. Nietzsche, Thus Spoke Zarathustra (Azbuka, Moscow, 2020)

7. A.P. Chekhov, Kryzhovnik [Gooseberries], in Collected works and correspondence: in 30 volumes. Collected works: in 18 volumes, 10, 55-65 (Russian Academy of Sciences. A.M. Gorky Institute of World Literature, Nauka, Moscow, 1977). Accessed on: December 5, 2020. [Online]. Available: http://chehovlit.ru/chehov/text/kryzhovnik.htm

8. F.M. Dostoevsky, Besy [Demons] (Rech, Moscow, 2017)

9. A. Maurois, Lettres à l'inconnue [To an Unknown Lady] (AST, Moscow, 2019)

10. M.V. Babalaeva, Viktor Frankl: filosofskoe istolkovanie smysla stradaniya [Viktor Frankl: a philosophical interpretation of the meaning of suffering]. Dissertation for the Candidate of Philosophical Sciences (Moscow, 2008)

11. I.V. Bardykova, Kontseptualizatsiya fenomena stradaniya v istorii kultury [Conceptualization of the phenomenon of suffering in cultural history]. Dissertation for the Candidate of Philosophical Sciences (Belgorod, 2007)

12. M.A. Bogdanova, Ideya schastya i sposoby ee aktualizatsii: na materiale russkogo i frantsuzskogo yazykov [The idea of happiness and the ways for its actualization: on the material of Russian and French]. Dissertation for the Candidate of Philological Sciences (Volgograd, 2010)

13. M.N. Koroleva, Schaste kak sotsiokulturnyi fenomen: sotsiologicheskii analiz [Happiness as a sociocultural phenomenon: sociological analysis]. Dissertation for the Candidate of Sociological Sciences (Moscow, 2013)

14. M.V. Lapukhina, Analitika sushchnosti schastya v russkoi traditsionnoi culture [Analysis of the essence of happiness in Russian traditional culture]. Dissertation for the Candidate of Philosophical Sciences (Tambov, 2006)

15. Ya.V. Parusimova, Stradanie kak filosofskaya kategoriya [Suffering as a philosophical category]. Dissertation for the Candidate of Philosophical Sciences (Orenburg, 2003)

16. S. Klimova, Study East European Thought, 1, 129-135 (2007)

17. R. Lauth, Dostojewski und sein Jahrhundert [Dostoevsky and his Century] (Bouvier, Bonn, 1986)

18. M. Hildermeir, Geschichte Russland: vom Mittelalter bis zur Oktoberrevolution [History of Russia: from the Middle Ages to the October Revolution] (C. H. Beck, Munchen, 2013)

19. T.A.W. Oddane, International Journal of Managing Projects in Business, 8(1), 33-57 (2015). https://doi.org/10.1108/IJMPB-10-2013-0060

20. M. Tang, C.H. Werner, Thinking Skills and Creativity, 24, 268-278 (2017). https://doi.org/10.1016/j.tsc.2017.04.001 